\title{
The Impact of Organizational Commitment on Job Performance
}

\author{
Submitted $05 / 01 / 19,1^{\text {st }}$ revision $18 / 02 / 19,2^{\text {nd }}$ revision $22 / 03 / 19$, accepted $10 / 04 / 19$
}

\author{
Suharto $^{1}$, Suyanto ${ }^{2}$, Nedi Hendri ${ }^{3}$
}

\begin{abstract}
:
Purpose: This research discusses the direct effect of multicultural competencies, organizational fairness and organizational commitment on job performance. The primary data was collected using explanatory survey.

Design/Methodology/Approach: The sample consists of 350 respondents who are civil servants in Central Lampung Regency, Metro municipality and East Lampung Regency. The requirement analysis test used normality Lilliefors, homogeneity, linearity and significance regression. The data analysis technique is SEM (Structural Equation Modeling) analysis.

Finding: The research results show that multicultural competence directly influences organizational fairness, multicultural competence directly influences organizational commitment, multicultural competence has no direct influence on job performance, organizational fairness directly influences organizational commitment, organizational fairness has no direct influence on job performance, and organizational commitment directly influences job performance.

Practical Implications: Organizational commitment consisting of the belief in organizational values and goals should be improved so that skills, effort and nature of work condition become better.

Originality/Value: The achievement of employees' performance result and output recognized by the organization where they work and characterized by skills, effort and nature of work conditions is the combination of the part which represents better employees' performance.
\end{abstract}

Keywords: Multicultural competencies, organizational fairness, organizational commitment, job performance.

JEL Codes: M51, M54.

Paper type: Research article.

\footnotetext{
${ }^{1}$ Faculty Economic of Universitas, Muhammadiyah Metro, Jl. Kihajar Dewantara 116 Kota Metro, Lampung, Indonesia, E-mail Correspondence: hartoumm@gmail.com

${ }^{2}$ Faculty Economic of Universitas, Muhammadiyah Metro, Jl. Kihajar Dewantara 116 Kota Metro, Lampung, Indonesia.

${ }^{3}$ Faculty Economic of Universitas, Muhammadiyah Metro, Jl. Kihajar Dewantara 116 Kota Metro, Lampung, Indonesia.
} 


\section{Introduction}

The large variety of cultural backgrounds in an organization empirically proves positive impact if each employee is placed according to their own habit (Barden et al., 2017). Cultural diversity is the strength of the organization when it is combined with respective strengths. Employees who have skills in communication are absolutely in different placements from other employees who have skills in equipment supervision that do not need to socialize with other employees (Yean \& Yusof, 2016).

Another empirical evidence proves that there are various factors affecting weak performance (Dajani, 2015). Some of these factors are organizational fairness, multicultural competencies and organizational commitment (Yean \& Yusof, 2016; Al Zeifiti \& Mohamad, 2017). Employee's performance will have beneficial value for an organization if the amount given by the organization exceeds the amount received by the organization (Kalay, 2016).

The combination of attitude, perception and behavior existing in the organization is a good strength when it is combined in accordance with the organizational goals (Aboazoum et al., 2015). The strength created can be used as a basic organizational competitiveness to deal with competing organizations. The culture and its consequences, fair organizational treatment to employees, commitment to organizations are the organizational strength of an organization. This strength is insurmountable and basic for enhancing employee's performance (Vincent \& Torres, 2015).

An organization will grow and develop if it is supported by multicultural elements (Hladik, 2012). Multiculturalism is a variety of behavior causing various job situations to be filled based on the needs of the job (Dietz et al., 2017). Individuals having the ability to be adapted by the business environment will have the speed to face the competition. In a relatively short time, they can decide to save the organization under certain situations (Borghei et al., 2010).

\section{Literature Review}

\subsection{Multicultural competence dan organizational fairness}

Multicultural competence is adopted by working experience in large groups and applied to small groups in the organization (Vincent \& Torres, 2015). Multicultural is learning experience in small groups that has been proven by large groups and can be promoted by their multicultural competencies (Dietz et al., 2017). The qualified multicultural competencies will create organizational fairness in the working groups (Ahmed et al., 2011). According to Al-Zu'bi (2010), organizational fairness relates to the ways in which employees can determine whether they have been treated fairly in their work and meet the requirements with the ways where the determination 
affects other related jobs. Organizational fairness refers to perceived fairness from social and economic exchange between employees and their work organizations (Rai, 2013; Suroso \& Anggraeni, 2017).

The ability of organizations in utilizing multicultural competence can improve organizational performance to achieve the fairness in treating employees. Hosgorur et al. (2017), Chen et al. (2015) state that organizational fairness is a concept that explains employees' perceptions of how fair they are treated in the organization and how these perceptions affect the organizational outcomes such as commitment and satisfaction. Based on this description it can be assumed that multicultural competence can affect organizational fairness.

\subsection{Multicultural competence and organizational commitment}

Organizational commitment includes strong confidence and acceptance of organizational goals and values; willingness to exert great effort on behalf of the organization; and strong desire to keep working with the organization (Dajani, 2015). Employees' ethic is the basis for creating good working relationship that refers to employees' intelligence to act in the organization. This differs from other forms of commitment such as work ethic support, career commitment, job involvement and union commitment that focuses on values, career and job (Borghei et al., 2010; Srivastava \& Tang, 2015; Rahman et al., 2015). Organizational commitment can be the degree in which an individual adopts organizational values in identifying problems to fulfill his job responsibilities (Mohammed \& Eleswd, 2013). According to Azeem (2010), Stinglhamber et al. (2015), strong desires in organizational goals and values, willingness to do a lot of effort on behalf of the organization and strong desire to remain a member of the organization is employees' ability in analyzing the performance of various cultures.

According to Hladik (2012), multicultural competence as "the awareness, knowledge and skills" is required for effective work across ethnic and cultural difference from various groups. Multicultural competence is mostly done by employees having the ability to understand and commit to the vision of the organization. Multicultural competence means a part for approaching the process of one's personality counseling (Ahmed et al., 2011). It means that multicultural competence is necessary for employees who have learned and are experienced in a small group. Besides, they have proven to be an effective approach in promoting their respective multicultural competence (Dietz et al., 2017; Barden et al., 2017). Based on this description, it can be assumed that multicultural competence directly influences organizational commitment.

\subsection{Multicultural competence and job performance}

Multicultural competence that exists in an organization is employees' ability to involve themselves in action or creating situations that maximize individual 
development (Vincent \& Torres, 2015). Furthermore, Hladik (2012) states that the awareness of the importance of existing skills and knowledge to improve skills employees' performance in working through cross-ethnicity and cultural differences from various groups must be owned by each member of the organization.

Multicultural competence also means a part of education approaching process from cultural context of each member of the organization, so it can improve work performance and can be used to achieve the organizational goals and used objectives (Jayaweera, 2015). Platis et al. (2014) state that work achievement related to work performance can be an important parameter in the organization. Multicultural competence which is well-allocated will produce new innovations and can be used to provide additional value for the organization (Dietz et al., 2017; Barden et al., 2017). Based on this description it can be assumed that multicultural competence directly influences job performance.

\subsection{Organizational fairness and organizational commitment}

Management of existing organizations in the company or institution is a strength formed through the mechanism of utilization of existing functions (Chen et al., 2015). Each unit playing role in the organization has equal rights and obligations. Therefore, the fairness of resources desired by each employee can be realized by the organization where they are working (Yean \& Yusof, 2016).

Organizational fairness is an evaluation process of administrative decision made by employees in terms of division of employees' duties, compliance with shifts, empowerment, level of salary, achievement distribution and economic application (Kalay, 2016). Employees want such a fair social work environment, perceptions in internal decision-making and how these decisions are shared so that their commitment to the organization is getting stronger (Al-Zu'bi, 2010).

Parts of organizational fairness relate to the ways in which employees can feel whether they have been treated fairly by the organization in their work and in a certain period, their attitude formed can influence commitment to the organization (Al-Zu'bi, 2010; Hosgorur et al., 2017). Organizational commitment includes strong confidence and acceptance of organizational goals and values; willingness to exert great effort on behalf of organization; and strong desire to keep working with the organization (Neubert \& Halbesleben, 2015; Zachary, 2013). Organizational commitment refers to the attachment of employees to an organization. It differs from other forms of commitment such as work ethic support, career commitment, job involvement and union commitments that focus on values, career, job and labor union, respectively (Dajani, 2015; Borghei, 2010).

According to Al Zeifeti \& Mohamad (2017), organizational commitment as the "willingness of social actors to provide their energy and loyalty to the social system, the attachment of the social system of personality relationships that is considered as 
self-expression". Organizational commitment can be the degree in which an individual adopts organizational values and goals and identifies with them in fulfilling their working responsibility (Mohammed \& Eleswd, 2013).

Organizational fairness refers to perceived fairness from social and economic exchange between employees and their work organizations (Rai, 2013; Chen et al., 2015). On the other hand, organizational commitment is strong belief for organizational goals and values, willingness to do a lot of effort on behalf of organization and desire to remain a member of the organization (Azeem, 2010; Sharma \& Sinha, 2015). Based on the description, it can be assumed that organizational fairness directly influences organizational commitment.

\subsection{Organizational fairness and job performance}

Organizational fairness relates to the ways of employees who can feel that they have been treated fairly in their work, so it affects their advanced work to achieve the organizational goals and objectives (Jayaweera, 2015; Al-Zu'bi, 2010; Rai, 2013). The fairness perceived by employees is social and economic exchange among employees, so they are aware that they are highly appreciated by the organization (Hosgorur et al., 2017; Chen et al., 2015).

Work achievement is considered as an important parameter in the employee profession, in which the results obtained by employees can be done fairly. The fairness obtained by the organization can improve employees' performance (Platis et $a l ., 2014)$. The working result recognized by the organization is done by employees who can adopt the skills and effort. Characteristic of work condition is a combination that is expressed as a part that represents the work performance obtained from fair treatment (Ling \& Bhatti, 2014).

Yozgat et al. (2013) state that job performance as the function of individual performance on the specific tasks consisting standard job description. In addition, they state that job performance is also influenced by variables such as maintaining good interpersonal relationship, absenteeism, withdrawal behavior and other behaviors that increase danger in workplace. Based on the description, it can be assumed that organizational fairness directly influences job performance.

\subsection{Organizational commitment and job performance}

Commitment to a good organization can improve one's performance in the company (Khan et al., 2010). According to Mohammed \& Eleswd (2013), organizational commitment is the degree in which individuals adopt organizational values and goals and identifies with them in fulfilling their job responsibility. A strong belief in organizational values and goals, willingness to do a lot of effort on behalf of the organization and strong desire to remain a member of the organization can motivate employees to work better (Azeem, 2010; Al Zeifeti \& Mohamad, 2017). 
Ling \& Bhatti (2014) propose that employees' achievement and output recognized the organization where they work and characterized by skills, effort and nature of the work condition are the combination expressed as a part that represents job performance. A good work result will be obtained when employees have strong commitment to the organization and a psychological attachment to the organization (Al Zeifeti \& Mohamad, 2017; Sharma \& Sinha, 2015).

Organizational commitment is the social actors' willingness to provide their effort and loyalty to the social system (Lapointe et al., 2018). The attachment to the personality system of social relations can be self-expression, so it can increase employees' morale and behavior to work better and produce their work achievement (Jayaweera, 2015; Platis et al., 2014). Work achievement is considered as an important parameter in the organization and it recognized as a profession to find innovative ways for organizational progress (Aboazoum et al., 2015). Based on this description, it can be assumed that organizational commitment positively influences job performance.

\section{Methodology}

This research was conducted in three regional government secretariat offices, in Central Lampung regency, East Lampung regency and Metro municipality. The researchers assumed that each government office in these three different locations has the highest cultural variation compared to other cities in Lampung province. Variations in distance traveled by employees, especially in East Lampung and Central Lampung regencies are very high due to the transformation of Central Lampung regency into Metro municipality implemented by the Government since 2010. Most of the employees who live in Metro municipality, still stay even though their office location is moved from Metro municipality to Central Lampung and East Lampung.

The research on performance measurement using factors such as motivation, organizational commitment and organizational fairness has been done before. However, the research on performance measurement using mediating variables of organizational commitment is still infrequent to be done due to various reasons. The existence of political atmosphere in employee's placement based on the interests of certain parties. In addition, most of the government officials who have been accepted and worked as civil servants have not been selected through a strict mechanism of selection examination (Fatimah, 2018). Therefore, the mental and personality of the government apparatus are not qualified enough compared to the employees of the private institutions who have already done the selection examination with strict qualifications.

The research method used causal survey, by distributing questionnaires to the respondents. The research instrument used was designed to obtain the information about variable used by the researchers. The research analysis was conducted by 
using the score data of each item of multicultural competence, organizational fairness, organizational commitment and job performance.

Due to the examination of the influence between exogenous and endogenous variables, which is the influence of multicultural competence, organizational fairness, organizational commitment on employees' job performance, therefore, the examination tools used in this research are inferential statistics namely linearity test analysis, regression significance, homogeneity and normality, and structural equation modeling (Bagozzi \& Fornell, 1982; Fatimah, 2017). The package used was linier structural relationship program (LISREL), a statistical program package for modeling structural equation (Wijanto, 2008).

Based on the research background, the direct influence between exogenous and endogenous variables was described in the form of a constellation model and it followed the rules that have been set. The research samples taken were 350 government officials in Central Lampung, Metro municipality and East Lampung as the respondents (Slovin, 2003). The determination of the number of the sample was based on proportional random sampling (Hair, 2009; Andriyansah \& Aryanto, V.D.W 2017).

Meanwhile, the sampling technique used is besed on a random sample. The instrument validity was examined using biserial correlation (Naga, 1992; Bluman, 2008) and the reliability used internal consistency reliability coefficient (Steiner, 2003; Cronbach, 1963). The instrument scale was multi competence, organizational fairness, organizational commitment, and job performance.

\section{Research Results}

Before the data analysis is conducted, it is necessary to examine the analysis requirements as follows in Tables 1-3:

Table 1. The Summary of the Test Requirements of the Normality

\begin{tabular}{|l|l|l|l|l|l|}
\hline No. & $\begin{array}{l}\text { Error Estimated } \\
\text { Regression }\end{array}$ & $\mathrm{L}_{\text {value }}$ & $\mathrm{L}_{\text {table }}$ & Decision & Conclusion \\
\hline 1. & $\mathrm{Y}_{2}$ on $\mathrm{X}_{1}$ & 0.026 & 0.046 & $\mathrm{H}_{0}$ Acceptable & Normal \\
\hline 2. & $\mathrm{Y}_{2}$ on $\mathrm{X}_{2}$ & 0.056 & 0.046 & $\mathrm{H}_{0}$ unacceptable & Abnormal \\
\hline 3. & $\mathrm{Y}_{2}$ on $\mathrm{Y}_{1}$ & 0.032 & 0.046 & $\mathrm{H}_{0}$ Acceptable & Normal \\
\hline 4. & $\mathrm{Y}_{1}$ on $\mathrm{X}_{1}$ & 0.028 & 0.046 & $\mathrm{H}_{0}$ Acceptable & Normal \\
\hline 5. & $\mathrm{Y}_{1}$ on $\mathrm{X}_{2}$ & 0.032 & 0.046 & $\mathrm{H}_{0}$ Acceptable & Normal \\
\hline 6. & $\mathrm{X}_{2}$ on $\mathrm{X}_{1}$ & 0.056 & 0.046 & $\mathrm{H}_{0}$ unacceptable & Abnormal \\
\hline
\end{tabular}


Table 2. The Summary of the Test Requirements of the Homogeneity

\begin{tabular}{|l|l|l|l|l|l|}
\hline No. & Variable & $\mathrm{X}_{\text {value }}^{2}$ & $\mathrm{X}_{\text {table }}^{2}$ & Decision & Conclusion \\
\hline 1. & $\mathrm{Y}_{2}$ on $\mathrm{X}_{1}$ & 86.45 & 373 & $\mathrm{H}_{0}$ Acceptable & Homogenous \\
\hline 2. & $\mathrm{Y}_{2}$ on $\mathrm{X}_{2}$ & 97.43 & 367 & $\mathrm{H}_{0}$ Acceptable & Homogenous \\
\hline 3. & $\mathrm{Y}_{2}$ on $\mathrm{Y}_{1}$ & 66.24 & 364 & $\mathrm{H}_{0}$ Acceptable & Homogenous \\
\hline 4. & $\mathrm{Y}_{1}$ on $\mathrm{X}_{1}$ & 140.97 & 373 & $\mathrm{H}_{0}$ Acceptable & Homogenous \\
\hline 5. & $\mathrm{Y}_{1}$ on $\mathrm{X}_{2}$ & 136.52 & 367 & $\mathrm{H}_{0}$ Acceptable & Homogenous \\
\hline 6. & $\mathrm{X}_{2}$ on $\mathrm{X}_{1}$ & 76.54 & 373 & $\mathrm{H}_{0}$ Acceptable & Homogenous \\
\hline
\end{tabular}

Table 3. The Summary of the test of Requirements and the significance Linearity Regression

\begin{tabular}{|l|l|l|l|l|l|l|}
\hline \multirow{2}{*}{ Variable } & \multicolumn{2}{|l|}{$\begin{array}{l}\text { Sig. } \\
\text { Regression }\end{array}$} & \multirow{2}{*}{ Sig. Regression } & \multicolumn{2}{l|}{$\begin{array}{l}\text { lin. } \\
\text { Regression }\end{array}$} & \multirow{2}{*}{$\begin{array}{l}\text { Linearity of } \\
\text { Regression }\end{array}$} \\
\cline { 2 - 3 } \cline { 5 - 6 } & $\mathrm{F}_{\text {value }}$ & $\mathrm{F}_{\text {table }}$ & & $\mathrm{F}_{\text {value }}$ & $\mathrm{F}_{\text {table }}$ & \\
\hline $\mathrm{Y}_{2}$ on $\mathrm{X}_{1}$ & 18.21 & 2.72 & Significant & -0.10 & -2.72 & Linearity \\
\hline $\mathrm{Y}_{2}$ on $\mathrm{X}_{2}$ & 0.58 & 2.72 & Insignificant & 0.16 & 2.72 & Linearity \\
\hline $\mathrm{Y}_{2}$ on $\mathrm{Y}_{1}$ & 61.93 & 2.72 & Significant & 0.10 & 2.72 & Linearity \\
\hline $\mathrm{Y}_{1}$ on $\mathrm{X}_{1}$ & 44.59 & 2.72 & Significant & 0.02 & 2.72 & Linearity \\
\hline $\mathrm{Y}_{1}$ on $\mathrm{X}_{2}$ & 116.67 & 2.72 & Significant & 0.08 & 2.72 & Linearity \\
\hline $\mathrm{X}_{2}$ on $\mathrm{X}_{1}$ & 165.38 & 2.72 & Significant & -0.10 & -2.72 & Linearity \\
\hline
\end{tabular}

\subsection{Result of the Path Coefficient Calculation, $t_{\text {value }}$}

After the examination of the required analysis, the next step is to calculate and examine each path coefficient presented in Table 4 as follows:

Table 4. Result of the Path Coefficient Calculation ( $\left.t_{\text {value }}\right)$

\begin{tabular}{|l|l|l|l|l|l|}
\hline \multirow{2}{*}{ No. } & \multirow{2}{*}{ Variable } & \multicolumn{2}{|l|}{ The Path Coefficients $(\rho)$} & \multirow{2}{*}{ Decision } & Conclusion \\
\cline { 3 - 4 } & & SLF* & $\mathrm{t}_{\text {value }}$ & & \\
\hline 1. & $\mathrm{Y}_{2}$ on $\mathrm{X}_{1}$ & 0.03 & 0.35 & $\mathrm{H}_{0}$ Acceptable & Insignificant \\
\hline 2. & $\mathrm{Y}_{2}$ on $\mathrm{X}_{2}$ & 0.10 & 1.14 & $\mathrm{H}_{0}$ Acceptable & Insignificant \\
\hline 3. & $\mathrm{Y}_{2}$ on $\mathrm{Y}_{1}$ & 0.30 & 4.13 & $\mathrm{H}_{0}$ Unacceptable & Significant \\
\hline 4. & $\mathrm{Y}_{1}$ on $\mathrm{X}_{1}$ & 0.32 & 4.42 & $\mathrm{H}_{0}$ Unacceptable & Significant \\
\hline 5. & $\mathrm{Y}_{1}$ on $\mathrm{X}_{2}$ & 0.16 & 2.27 & $\mathrm{H}_{0}$ Unacceptable & Significant \\
\hline 6. & $\mathrm{X}_{2}$ on $\mathrm{X}_{1}$ & 0.59 & 9.52 & $\mathrm{H}_{0}$ Unacceptable & Significant \\
\hline
\end{tabular}

Note: *Standardized Loading Factor.

\subsection{The Path coefficient Sub-Structure 1}


The analysis model of the path coefficient Sub-Structure 1 is described in the form of equation $X_{2}=\rho_{21} X_{1}+\varepsilon_{1}$. This examination will provide a decision-making of hypothesis test 1 as shown in Figure 1:

Figure 1. The Path coefficient Sub-Structure 1

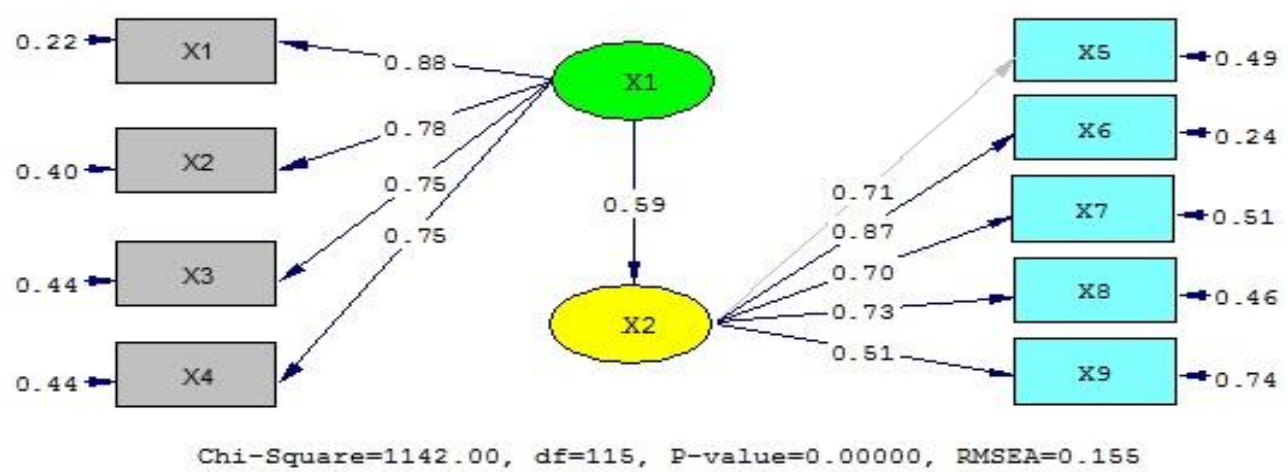

Based on the examination of sub-structure 1 , the $\left(\rho_{21}\right)$ path coefficient is 0.59 with the value $t_{\text {value }}=9.52>t_{\text {table }(0.05: 375)}=1.65$. Therefore, $H_{0}$ is rejected and the $\left(\rho_{21}\right)$ path coefficient is significant, which means that multicultural competence directly influences organizational fairness.

\subsection{The Path coefficient Sub-Structure 2}

The analysis model of the path coefficient Sub-Structure 2 is described in the form of equation $Y_{1}=\rho_{31} X_{1}+\rho_{32} X_{2}+\varepsilon_{1}$. This examination will provide a decisionmaking of hypothesis test 2 and 3 as shown in Figure 2:

Figure 2. The Path coefficient Sub-Structure 2

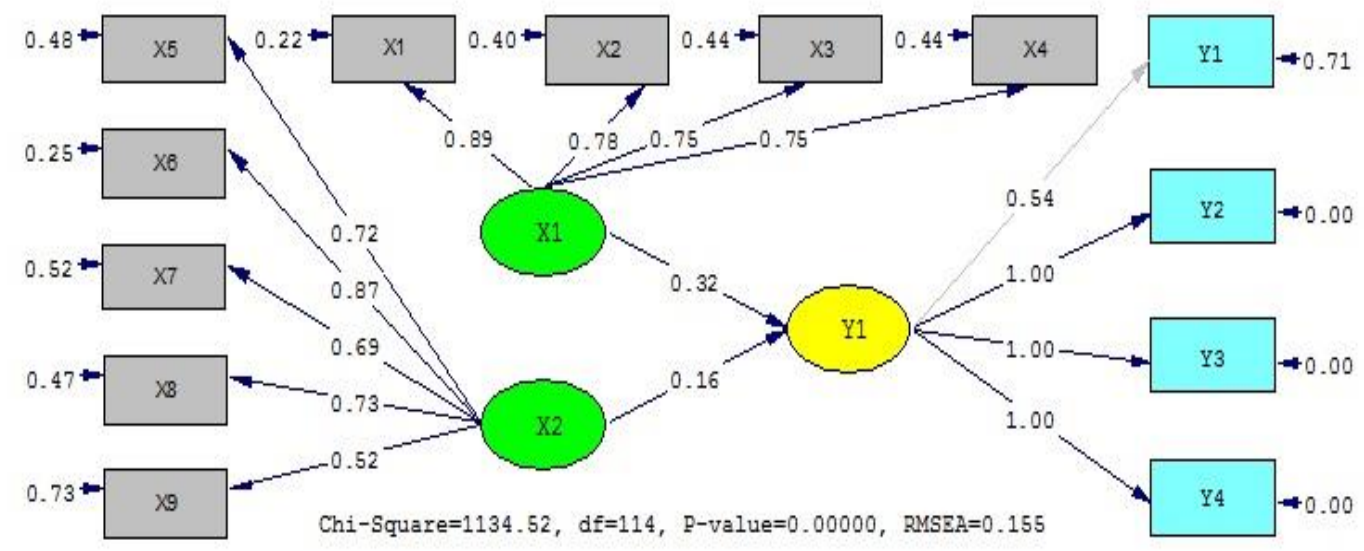


Based on the examination of sub-structure 2, the $\left(\rho_{31}\right)$ path coefficient is 0.32 and the value $t_{\text {value }}=4.42>t_{\text {table }(0.05: 360)}=1.65$. Therefore, $H_{0}$ is rejected and the $\left(\rho_{31}\right)$ path coefficient is significant, which means that multicultural culture positively influence organizational commitment. The $\left(\rho_{32}\right)$ path coefficient is 0.16 and $t_{\text {value }}=2.27>t_{\text {table }}$ $(0,05: 360)=1.65$, therefore $H_{0}$ is rejected and the $\left(\rho_{32}\right)$ path coefficient is significant, which means that organizational fairness positively influences organizational fairness.

\subsection{The Path coefficient Sub-Structure 3}

The analysis model of the path coefficient Sub-Structure 3 is described in the form of equation $Y_{2}=\rho_{41} X_{1}+\rho_{42} X_{2}+\rho_{43} Y_{1}+\varepsilon_{2}$. This examination will provide a decision-making of hypothesis test 4, 5 and 6 as shown in Figure 3:

Figure 3. The Path coefficient Sub-Structure 3

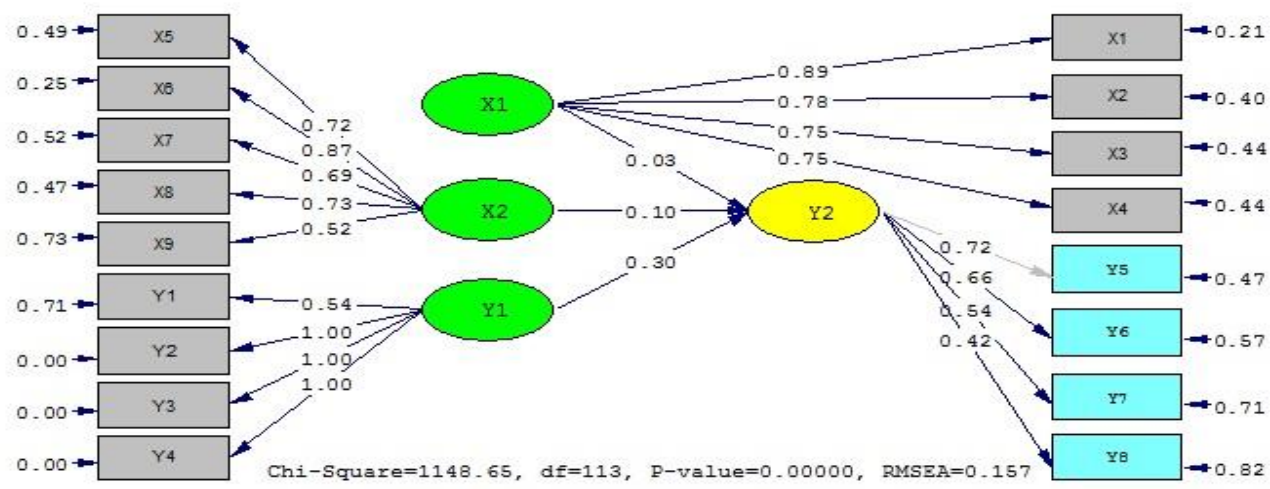

Based on the examination of sub-structure 3 , the $\left(\rho_{41}\right)$ path coefficient is -0.03 and $\mathrm{t}_{\text {value }}=0.35<\mathrm{t}_{\text {table }(0.05: 375)}=1.65$. Therefore, $\mathrm{H}_{0}$ is accepted and the $\left(\rho_{41}\right)$ path coefficient is not significant. It means that multicultural competence does not directly influence job performance. The $\left(\rho_{42}\right)$ path coefficient is 0.10 and $t_{\text {value }}=1.14$ $<\mathrm{t}_{\text {table }(0,05: 360)}=1.65$, therefore $\mathrm{H}_{0}$ is accepted and the $\left(\rho_{42}\right)$ path coefficient is significant. It means that organizational fairness does not directly influence job performance positively. The $\left(\rho_{43}\right)$ path coefficient is 0.30 and $t_{\text {value }}=4.13>t_{\text {table }}(0.05$ ${ }_{360}=1.65$, therefore $\mathrm{H}_{0}$ is rejected and the $\left(\rho_{43}\right)$ path coefficient is significant. It means that organizational commitment positively influences job performance.

\subsection{The Path Model}

Based on the path model calculation and $t$-value for hypothesis examination shown in Figure 4, four coefficients have significant values $<0.05$ or $t$-value $>1.65$. Therefore, $\mathrm{H}_{0}$ is rejected and $\mathrm{Ha}$ is accepted, while the other two path coefficients 
are not significant because the value of significant path coefficient $>0.05$ or $t$-value $<1.65$.

\section{Figure 4. The Path Model with t-value}

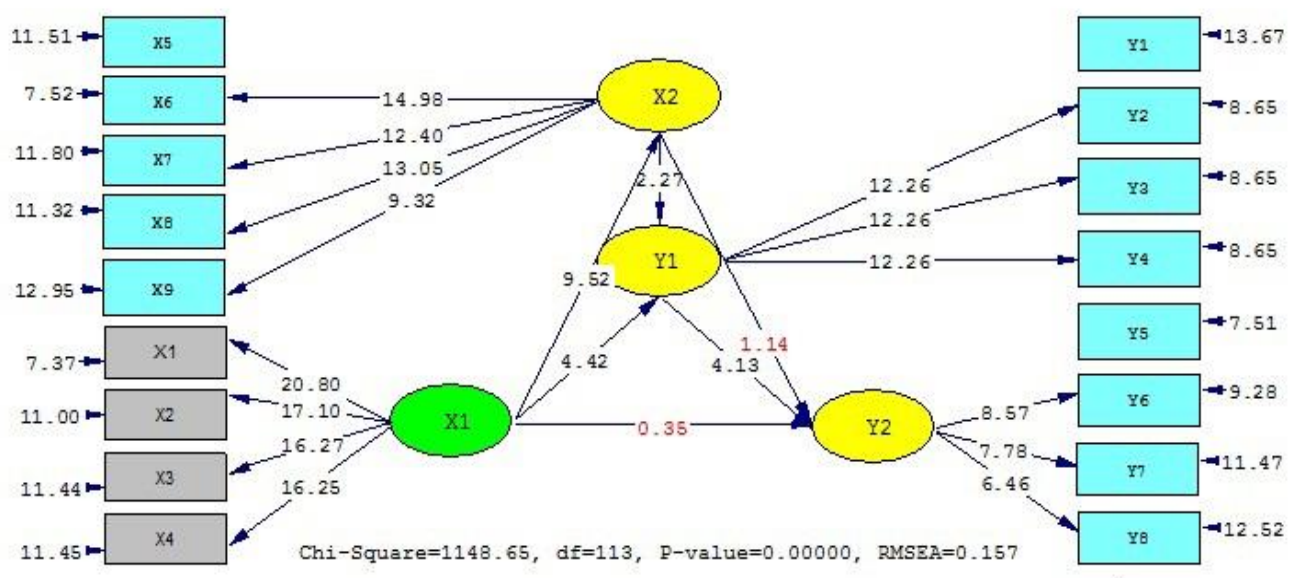

Overall, the diagram of standardized solution path on each variable through Lisrel versi 8.80 program is described in Figure 5 as follows:

Figure 5. Diagram of Standardized Solution Path

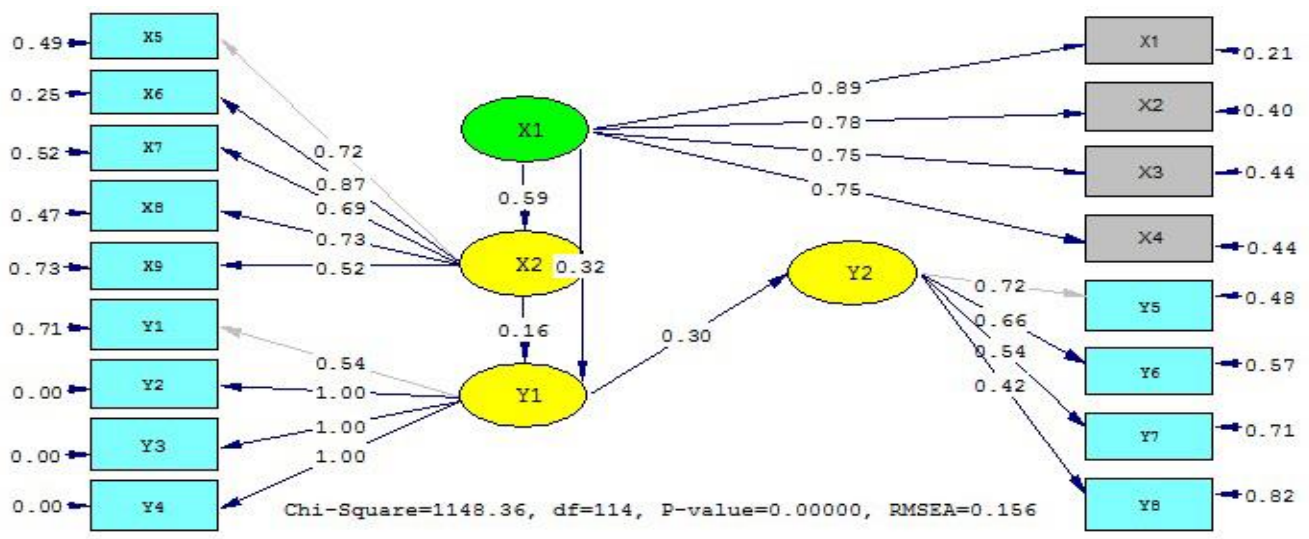

Based on Figure 5 (diagram of standardized solution path), in addition to the direct influence, there is also total and indirect influence between exogenous variables $(\mathrm{X})$ and endogenous variables (Y). Based on the lisrel output on standardized total effect, it shows that:

(1) there is a direct effect of three variables namely, multicultural competence $\left(X_{1}\right)$, organizational fairness $\left(\mathrm{X}_{2}\right)$ and organizational commitment $\left(\mathrm{Y}_{1}\right)$ on job performance 
$\left(\mathrm{Y}_{2}\right)$ presented by each path coefficient being $0.59,0.32,0.16$, and 0.30 because it is not mediated by other variables (intervening variables);

(2) the total effect two variables namely, multicultural competence $\left(\mathrm{X}_{1}\right)$ and organizational fairness $\left(\mathrm{X}_{2}\right)$ on organizational commitment $\left(\mathrm{Y}_{1}\right)$ is equal to the total value of direct effect on each variable, because it is mediated by other variables (intervening variables) of organizational fairness $\left(\mathrm{X}_{2}\right)$;

(3) there is indirect effect of one variable namely, multicultural competence $\left(\mathrm{X}_{1}\right)$ on organizational commitment $\left(\mathrm{Y}_{1}\right)$ being $0.59 \times 0.16=0.094$, because there is another variable (intervening variable) namely organizational fairness $\left(\mathrm{X}_{2}\right)$. Meanwhile, the total effect is $0.59+0.16=0.74$;

(4) there is indirect effect of one variable namely, multicultural competence $\left(\mathrm{X}_{1}\right)$ on job performance $\left(\mathrm{Y}_{2}\right)$ being $0.32 \times 0.30=0.096$, because there is another variable (intervening variable) namely organizational commitment $\left(\mathrm{Y}_{1}\right)$. Meanwhile, the total effect is $0.32+0.30=0.62$;

(5) there is indirect effect of one variable namely, organizational fairness $\left(\mathrm{X}_{2}\right)$ on job performance $\left(\mathrm{Y}_{2}\right)$ being $0.16 \times 0.30=0.048$, because there is another variable (intervening variable) namely organizational commitment $\left(\mathrm{Y}_{1}\right)$. Meanwhile, the total effect is $0.16+0.30=0.46$.

The above description of the total effect of exogenous variable $(\mathrm{X})$ on endogenous variable $(Y)$ shows that $\mathrm{X}_{1}$ variable has direct influence on $\mathrm{X}_{2}$ variable. $\mathrm{X}_{1}$ variable has direct influence on $\mathrm{Y}_{1}$ variable. $\mathrm{X}_{2}$ variable has direct influence on $\mathrm{Y}_{1}$ variable. $\mathrm{Y}_{1}$ variable has direct influence on $\mathrm{Y}_{2}$ variable. The influence of $\mathrm{X}_{1}$ variable on $\mathrm{X}_{2}$ variable has the largest value of influence compared to other variables that are not mediated by other variables. In other words, multicultural competence $\left(\mathrm{X}_{1}\right)$ and organizational fairness $\left(\mathrm{X}_{2}\right)$ have the largest influence value compared to only one variable that influences organizational commitment $\left(\mathrm{Y}_{1}\right)$. The variable of multicultural competence $\left(\mathrm{X}_{1}\right)$ and organizational fairness $\left(\mathrm{X}_{2}\right)$ have no direct influence on performance $\left(\mathrm{Y}_{2}\right)$.

\subsubsection{Multicultural competence has direct positive influence on organizational fairness}

This finding shows that multicultural competence is well-conducted, in which employees' ability is improved in the organization consisting of individuals' ability to interact with their work environment, accept the existing culture variations due to diverse cultures and habits. Therefore, organizational fairness related to the ways where employees can determine whether they have been treated fairly in their work and meet the requirements with the ways where the determination affects other related jobs. Organizational fairness refers to perceived fairness from social and economic exchange among employees. This finding is in accordance with Vincent \& Torres's research (2015) where multicultural competence is the ability to engage in action or create conditions that maximize the optimal development of individuals or individual system (Hladik, 2012). 


\subsubsection{Multicultural competence has direct positive influence on organizational commitment}

The finding shows that multicultural competence has direct positive influence on organizational commitment. It indicates that if the skills needed to achieve effective performance are fulfilled by employees through work environment with crossculture and different culture from various groups, then individuals' ability who work in the organization and use all their capabilities to improve organizational performance will increase. Employees will improve their ability to understand and commit to the organizational goals. Employees competence where they understand multicultural and are intelligent in using their emotions to understand various cultures in their work environment will involve themselves in action and create individual conditions to work in the organization. Employees commit to work hard with strong desire and be open-minded to the organizational goals and values. This finding is in accordance with the research by Hladik et al. (2012), who state that multicultural competence influences organizational commitment.

\subsubsection{Multicultural competence has no direct positive influence on job performance}

The finding shows that multicultural competence has no direct positive influence on job performance. It indicates that if employees are aware and have skills to utilize the existing cross-culture in their work environment of the organization, then new values created by employees to improve the additional value for each duty they will not increase significantly. The existing potential on each employee will be less developed in accordance with the interests of the organization. Various existing culture will not be a strength to create the potential which improve employees' performance. This finding is not relevant to the research by Dietz et al., (2017) and Barden et al. (2017) who state that multicultural competence influence job performance.

\subsubsection{Organizational fairness has direct positive influence on organizational commitment}

The finding shows that organizational fairness has direct positive influence on organizational commitment. It indicates that if an evaluation of administrative decision made by employees in terms of division tasks, empowerment of employees' rights and obligations is increased, then employees' willingness to increase energy and loyalty on social system of the organization will increase. Employees can express and socially interact to improve commitment to the organization through their ability to adopt common values and responsibilities given to the organization. Therefore, the fairness given by the organization to employees will be positively perceived by employees to increase commitment and loyalty to the organization. This finding is in accordance with the research by Rai (2013) and Chen et al. (2015) who state that organizational fairness has influence on organizational commitment. 


\subsubsection{Organizational fairness has no direct positive influence on job performance}

The finding shows that organizational fairness has no direct positive influence on job performance. It indicates that fairness of resources received by employees in the organization in the form of equality of rights and obligations acceptance of the organization's performance, then the findings created by employees to additional value in each task they will not increase significantly. The existing employees' competence which is less developed is in accordance with the organizational goals. Various perceptions about fairness which is developing among employees are less supportive if it will be used as a strength to create competence in improving employees' performance. This finding is not relevant with the research by Platis et al. (2014) and Ling and Bhatti (2014) who state that organizational fairness influence job performance.

\subsubsection{Organizational commitment has direct positive influence on job performance}

The finding shows that organizational commitment has direct positive influence on job performance. It indicates that if employees have strong beliefs, accept the existing value set by the organization, have willingness to do a lot of effort for the organization, keep working with high commitment, then the result of work achieved will increase. The achievement of employees' performance result and output recognized by the organization where they work and characterized by skills, effort and nature of work conditions is the combination of the part which represents better employees' performance. A good work result will be obtained when employees have strong commitment to the organization and a psychological attachment to the organization. This result is relevant with the research by Sharma and Sinha (2015), and Al Zeifeti and Mohamad (2017) who state that there is significant influence among organizational commitment and job performance.

\section{Conclusion}

Based on the research, the following conclusions can be made:

a. Multicultural competence influences organizational fairness. It shows that if individuals' ability to interact with their work environment is improved, organizational fairness is better evaluation process of employees' administrative decision. Therefore, it can be concluded that multicultural competence is in accordance with employees' perceptions and expectations.

b. Multicultural competence influences organizational commitment. It shows that if cultural variations existing in the organization can be optimized, awareness of the importance of skills and knowledge can improve employees' performance that will be better. Therefore, it can be concluded that multicultural competence is in accordance with employees' perceptions and expectations.

c. Multicultural competence influences job performance. It shows that if cultural variations existing in the organization is used as positive potential used by the organization, new innovations that provide additional value can be increased. 
Therefore, it can be concluded that multicultural competence is in accordance with employees' perceptions and expectations.

d. Organizational fairness influences organizational commitment. It shows that the fairness of the resource expected by employees can be realized by their organization. Therefore, promotion of work ethics, career commitment, employees' involvement in their work can be improved. It can be concluded that organizational fairness is in accordance with employees' expectations.

e. Organizational fairness influence job performance. It shows that if each existing unit has a role in the organization, the existence of fairness and important parameter in the employee profession, then employees' achievement in the output recognized by the organization can be increased. Therefore, it can be concluded that organizational fairness is in accordance with employees' expectations.

f. Organizational commitment influence job performance. It shows that if organizational commitment that includes strong belief and acceptance of organizational values and goals is getting better, then employees' work characterized with skills, effort and nature of work condition will be better. Therefore, it can be concluded that organizational fairness is in accordance with employees' expectations.

\section{Suggestions}

Based on the research the following suggestions can be made:

a. Multicultural competence consisting of individuals' ability to interact with their work environment which consists of various cultures should be improved so that employees' perception on organizational fairness can be better.

b. Multicultural competence consisting various cultures in the organization can be optimized so that the awareness of the importance of skills and knowledge to improve employees' performance can be increased.

c. Organizational fairness consisting of fairness of resource expected by employees can be realized by their organization so that work ethic support, career commitment and employees' involvement on their work can be improved.

d. Organizational commitment consisting of the belief in organizational values and goals should be improved so that skills, effort and nature of work condition can be better.

\section{References:}

Aboazoum, Hassan, M.E., Umar Nimran, Mochammad Al Musadieq. 2015. Analysis Factors Affecting Employees Job Performance in Libya. Journal of Business and Management, Vol. 17, 42-49.

Ahmed, S., Keith, B. Wilson, R.C., Henriksen. Jr.J., Wind, W.J. 2011. What Does it Mean to Be a Culturally-Competence Counselor. In the Special Issue on Multicultural Social Justice Leadership Development Guest. Journal for Social Actions in Counseling and Psychology, Vol. 3, 17-28. Editor: Carlos P. Zalaquett, University of South Florida. 
Al Zeifiti, Salim Musabah Bakhit \& Mohamad, Noor Azmi. 2017. The Influence of Organizational Commitment on Omani Public Employees' Work Performance. International Review of Management and Marketing, Vol. 7, 151-160.

Albdour, Ali Abbaas \& Altarawneh, Ikhlas I. 2014. Employee Engagement and Organizational Commitment: Evidence from Jordan. International Journal of Business, 19(2), ISSN: 1083-4346.

Al-Zu'bi, Hasan, A. 2010. A Study of Relationship Between Organizational Justice and Job Satisfaction. International Journal of Business and Management, Vol. 5, 102-109.

Andriyansah \& Aryanto, V.D.W. 2017. A Structural Equation Modelling Approach on Tourism Mega Event of Total Solar Eclipse and Customer Value in Belitung, Indonesia. International Journal of Mechanical Engineering and Technology, 8(6), 317-326.

Anwar, K. 2016. The Relationship Between Employee Commitment and Sustained Productivity in Agricultural Businesses. International Journal of Management and Applied Science, Volume 2, Issue1.

Azeem, Syed, Moh. 2010. Job Satisfaction and Organizational Commitment among Employees in the Sultanate of Oman. Psychology Journal, Vol. 1, 295-299.

Bagozzi, R.P. \& Fornell, C. 1982. Theoretical concepts, measurements, and meaning, in Fornell, C. (Ed.), A Second Generation of Multivariate Analysis, Vol. 1, Praeger, New York, 24-38.

Barden, S.M., Renee, S., Sherrell, J., Matthews, J. 2017. A National Survey on Multicultural Competence for Professional Counselors: A Replication Study. Journal of Counseling and Development, 95(2), 203-212.

Bluman, A.G. 2008. Elementary Statistics: A Step by Step Approach. New York: McGraw Hill.

Borghei, R., Gholamreza, J., Hasan, Z.M., Nasrin, D. 2010. An Examination of the Relationship between Empowerment and Organizational Commitment. International Journal of Humans Sciences, Vol. 7, 1155-1171.

Chen, Su-Yueh., Wen-Chuan Wu, Ching-Sheng Chang, Chia-Tzu Lin, Jung-Yuan Kung, Hui-Ching Weng, Yu-Tz Lin and Shu-I Lee. 2015. Organizational Justice, Trust, and Identification and Their Effects on Organizational Commitment in Hospital Nursing Staff. Journal of Health Service Sciences, Vol. 15, 1-17.

Chen, Y., Zhou, X. \& Klyver, K. 2018. Collective efficacy: Linking paternalistic leadership to organizational commitment. Journal of Business Ethics, 1-17, dx.doi.org/10.1007/ s10551-018-3847-9.

Cronbach, L.J. 1963. Educational Psychology. New York: Harcourt, Brace \& World, Inc.

Dajani, M., Ahmed, Z. 2015. The Impact of Employee Engagement on Job Performance and Organisational Comitment in the Egyptian Banking Sector. Journal of Business and Management Sciences, Vol, 3, 138-147.

Dietz, S., Santos, K.P., Dotson, B., Enselman, D., Jones, L., Sexton Jr.H.E., Waller, S.M., Richardson, M.E. 2017. An International Learning Experience: Looking at Multicultural Competence Development Through the Lens of Relational-Cultural Theory. Journal of Counselor Practice, 8(1), 22-44, DOI: 10.22229/ thg802643.

Fatimah, F., Rosadi, D., Hakim, R.F. \& Alcantud, J.C.R. 2017. A social choice approach to graded soft sets. In Fuzzy Systems (FUZZ-IEEE), 2017 IEEE International Conference on pp. 1-6, IEEE.

Fatimah, F., Rosadi, D. \& Hakim, R.B.F. 2018. Probabilistic soft sets and dual probabilistic soft sets in decision making with positive and negative parameters. In Journal of Physics: Conference Series, Vol. 983, No. 1. IOP Publishing. 
Hair, J.F. 2009. Multivariate Data Analysis. Edition 9. New Jersey: Pearson Education.

Handayani, S., Anggraeni, A. I. \& Rahardja, E. 2017. Analysis of Antecedent and

Consequence of Employee Engagement in Small and Medium-Sized Enterprises in

Central Java, Indonesia. European Research Studies, 20(3A), 500-513.

Hladik, J. 2012. Design and Development of a Multicultural Competence Scale in HelpingProfession Students. Asian Social Science, Vol. 10, No. 9, ISSN 1911-2017 EISSN 1911-2025.

Hosgorur, T., Althinkurt, Y. \& Kan, D. 2017. The Mediator Role of Organizational Justice in the Relationship Between Teachers' Prejudices in Their School Relations and Organizational Commitment: A Structural Equation Model. Educational Process: International Journal, 6(1), 37-52.

Jayaweera, T. 2015. Impact of Work Environmental Factors on Job Performance, Mediating Role of Work Motivation: A Study of Hotel Sector in England. International Journal of Bussines and Management, Vol. 10, 271-278.

Kalay, F. 2016. The Impact of Organizational Justice on Employee Performance: A Survey in Turkey and Turkish Context. International Journal of Human Resource Studies, Vol. 6, 1-20.

Khan, Muhammad Riaz, Ziauddin, Farooq Ahmed, M.I. Ramay. 2010. The Impacts of Organizational Commitment on Employee Job Performance. European Journal of Social Sciences, Volume 15, Number 3.

Lapointe, E., Vandenberghe, C. 2018. Examination of the Relationships Between Servant Leadership, Organizational Commitment, and Voice and Antisocial Behaviors. Journal of Bus Ethics, 109, 301-307, DOI 10.1007/s10551-011-1128.

Ling, Sai Mei \& Bhatti, Muhammad Awais. 2014. Work Stress and Job Performance in Malaysia Academic Sector: Role of Social Support as Moderator. British Journal of Economic, Management and Trade, Vol. 12, 1986-1998.

Mohammed, Fatima \& Eleswd, Muath. 2013. Job Satisfaction and Organizational Commitment: A Correlational Study in Bahrain. International Journal of Business, Humanities and Technology, Vol. 3, no. 5, 43-53.

Naga, D.S. 1992. Pengantar Teori Skor pada Pengukuran Pendidikan. Jakarta: Universitas Negeri Jakarta.

Neubert, M.J. \& Halbesleben, K. 2015. Called to commitment: An examination of relationships between spiritual calling, job satisfaction, and organizational commitment. Journal of Business Ethics, 132(4), 859-872, doi:http://dx.doi.org/10.1007/s10551-014-2336-z.

Peng, J., Jiang, X., Zhang, J., Xiao, R., Song, Y., Feng, X., Miao, D. 2013. The impact of psychological capital on job burnout of chinese nurses: The mediator role of organizational commitment. PLoS One, 8(12), doi.org/ 10.1371/ journal. pone. 0084193.

Platis, Ch., Reklitis, P., Zimeras, S. 2014. Relation Between Job Satisfaction and Job Performance in healtcare. Social and Bahavioral journal, Vol. 175, 480-487.

Rahman, Asim Rahman., Naveed Shahzad, Kiran Mustafa, Muhammad Fayaz Khan, Faizan Qurashi. 2015. Effects of Organizational Justice on Organizational Commitment. International Journal of Economics and Financial Issues, 6(S3), 188-196. ISSN: 2146-4138. Special Issue for "Asia International Conference (AIC 2015), 5-6 December 2015, Universiti Teknologi Malaysia, Kuala Lumpur, Malaysia".

Rai, G. 2013. Impact of Organizational Justice on Satisfaction, Commitment and Turnover Intention: Can Fair Treatment by Organizations Make a Difference in their 
Workers' Attitudes and Behaviors? International Journal of Human Sciences, Vol. 10, 260-284.

Sharma, P. \& Sinha, V. 2015. The Influence of Accupational Rankon Organizational Commitment of Faculty Members. Management Journal, Vol. 20, 71-91.

Slovin, C.G.S. 2003. Riset Pemasaran dan Perilaku, Alih Bahasa oleh Umar Husein. Jakarta: PT. Gramedia.

Steiner, D.L. 2003. Starting at the Beginning: An Introduction to Coefficient Alpha and Internal Consistency. Journal of Personality Assessment, Vol. 80, no. 1, 99-103.

Srivastava, R. \& Tang, T.L. 2015. Coping intelligence: Coping strategies and organizational commitment among boundary spanning employees. Journal of Business Ethics, 130 (3), 525-542, doi.org/10.1007/s10551-014-2234-4.

Stinglhamber, F., Marique, G., Caesens, G., Desmette, D., Hansez, I., Hanin, D. \& Bertrand, F. 2015. Employees' organizational identification and affective organizational commitment: An integrative approach. PLoS One, 10(4), dx.doi.org/10.1371/ journal.pone.0123955.

Suroso, A., Anggraeni, A.I. \& Andriyansah. 2017. Optimizing SMEs' Business Performance Through Human Capital Management. European Research Studies, 20(4B), 588599.

Vincent, S.K. \& Torres, R. 2015. Multicultural Competence: A Case Study of Teacher and their Student Perceptions. Journal Agricultural Educations, Vol. 56, 64-75.

Wijanto, Setyo, H. 2008. Structural Equation Modeling. Penerbit Graha Ilmu, Yogyakarta.

Yean \& Yusof. 2016. Organizational Justice: A Conceptual Discussion. Social and Behavioral Sciences, Vol. 219, 198-803.

Yozgat, U., Yurtkoru, S., Bilginoglu, E. 2013. Job Stress and Job Performance Among Employees in Public Sector in Istanbul: Examining the Moderating Role of Emotional Intelligence. Social and Behavioral Sciences, Vol. 75, 518-524.

Zachary, G.W. 2013. Spiritual Leadership: Investigating The Effects of Altruistic Love on Organizational Commitment. International Journal of Arts \& Sciences, 6(2), 767789. 